\title{
Factors Affecting Project Performance of Kenya Ports Authority
}

\author{
Jafeth Juma Akira*, Dr. Fridah Simba ** \\ * MSc Project Management Student, Jomo Kenya University of Agriculture and Technology, Kenya \\ jjuma@kpa.co.ke \\ ***Director, Jomo Kenyatta University of Agriculture and Technology (JKUAT), Kenya. \\ fridahtheuri@gmail.com.
}

\begin{abstract}
The study was aimed at assessing the factors affecting project performance of the Kenya Ports Authority (Port of Mombasa). Specifically, the study investigated the main key issues that affect the project performance with emphasis being made on the parameters; Project Management Procurement Process, Project Management Competency, Project Management Structure and the Project Management Organization Structure. The study employed the use of structured and Semi-structured questionnaires to collect data from a target population of 720, where $10 \%$ of the population was drawn and analyzed.

Cronbach's alpha $(\alpha)$ and Factor analysis (KMO \& Bartlett's Test of Sphericity) was used to determine the reliability and the validity of the research instrument respectively. The results showed that Procurement Process, PM Competency, PM Structure and PM Organization Culture have Cronbach's alpha above the acceptable lower limit of 0.7, hence a measure of internal consistency. The Pearson correlation analysis was used in the study to evaluate the relationship and the significant of dependent variable and the independent variable. ANOVA was used to compare the difference of means amongst the various groups. The obtained Fratio of 9.415 described the overall regression model as a good fit for the data. The results showed that the independent variables statistically significantly predicted the project performance.

The study recommended its findings to the management of the Port of Mombasa (KPA) on the best practice strategic Project Management, of which, when aligned to other parameters will enhance productivity, increased efficiency, customer satisfaction, and in the long run the organization will be able to achieve its Vision of being the "World Class Sea-ports of Choice".
\end{abstract}

Keywords: Project Performance, Competency, World class seaports,

\section{INTRODUCTION}

The Port of Mombasa has grown with time from safe harbors for fishing to trade hubs. Also with time the dynamics in trade has seen the Port growing significantly from bulk cargo transport to containerized shipments. This increased freight necessitated the development of infrastructures so as to handle the increased volumes and accommodate transhipment activities. The expansion in business and the desire to raise the investment capital and risk mitigation has gradually led to increased effort to manage the Port of Mombasa efficiently. Heavy capital outlay has been invested in various projects within the organization so as to realize the dreams of ports. The Government of Kenya has also seen it necessary to invest in the port infrastructure if it has to drive its economic sector, which is one of the pillars for the Kenya Vision 2030 (RoK, 2007).

\subsection{Statement of the Problem}

The Port of Mombasa (PoM) is a critical sector in the economic growth of Kenya and the integrated East African Community and despite some improvement, the Port is still faced with challenges, it's underperforming (World Bank, 2010). According to Kenya Economic update of June 2010, Kenya economy and other countries in East African which depends on imports and exports will grind to a halt. Kenya economic survey statistics of 2015 purports that export cargo generated USD 5.705billion while the imports generated USD 12.651billion. An Economic survey by KNBS stated that the trade balance worsened on account of a decline in exports and an increase in imports (RoK, 2014). Kenya's weak engine remains its exports which have been declining sharply. These statistics indicate the relevance of Port of Mombasa in its contribution to the national economy and if the Port could operate 
to full capacity, with reduced inefficiencies causing vessel delays, slow cargo clearance, loss of cargo then much of economic impact and benefits would be realized. It is also observes that impacts are evident only when investments are through and benefits measured.

Some of the few capital works aimed at improving the Port of Mombasa include; heavy investment of KES 450million, on Terminal Operating System like KWATOS which is meant to improve efficiency yet there is still uproar on inefficiencies within the Port of Mombasa. Abe \& Wilson (2009), eluded that investing in Port Infrastructure lower trade costs. The Port is still making effort to come to par with its international counterparts and faces serious challenges including inadequate capacity, inadequate infrastructure, high costs, labour inefficiency and inadequate equipment. This is the case for both the port and its inland container terminals (Trade Mark East Africa, 2014). The British High Commissioner Mr. Christian Turner in 2013 stated that "developed and efficiently operated Port unlock the economic potential of the region".

Port of Mombasa also invested in a state of the art Integrated Security System at a cost of KES 1.7 billion which was aimed at achieving the strategic goal; improving the security with the Port, both access and cargo and in conformity with the International Maritime Organization (IMO) standards and compliance with the International Ship and Port Facility Security (ISPS). The other components of the security system included Perimeter Detection System, CCTVs, Digital Video Recording, Access Control and Time Management System, Video Motion Detection System, Intrusion Detection System. Security Management software, Security Command and Control Centers, Printing of Security Documents and Security Communication System for the Kenyan seaport of Mombasa, (Rok, 2014).

According to the Auditor General's report on the ISS project, he asserted that it was not possible to ascertain if the Authority obtained value for money in procurement of the assets amounting to KES $105,568,932$ because critical issues; some containers into and out of the Port are not scanned by this equipment, recorded data are not available, some equipment are not fully functional etc (RoK, 2014). As much us there was no value addition on the previous contract, another contract on maintenance at a cost of KES293, 063, 544.90 was awarded. Time management component of the project has also faced some challenges during the project conception and implementation stage, It has failed to capture its desired objective that is to enhance productivity by ensuring employee spend time in port working. Njagi \& Malel (2012), states that time is proportional to productivity which directly translate to business profitability. The investment on infrastructures should translates to direct and indirect economic benefits of the organization and the region. For the Port of Mombasa, it's supposed to translate to improved productivity, customer satisfaction through efficient services, cargo security and safer Port, reduced transport cost and cost of good within the region.

According to KPA System Application Product (SAP), analysis of the overall capital works budget present a massive problem on the whole process and the concept of budgeting for capital works project. Port of Mombasa in 2014, the budget for 3.8billion on capital works project. There was a positive variance of $58.38 \%$ due to the fact that some of the proposed projects were not undertaken. The Overall budget for 2015 was 3.1 billion which was exceeded by $101.57 \%$ with some department surpassing the allocated budget for capital work projects by $239.11 \%$. This trend is similar the current year 2016; 4.8billion budgeted for has been exceeded by $105.8 \%$. This analysis also stipulates that some project were never implemented despite being budgeted for. In the financial year (FY) 2017, 15 billion has been allocated for capital works project. The trend observed from this statistics reveal a serious concerns on managing projects at the Port of Mombasa. The projects are ambitious and not aligned to the strategic vision of the organization; substantial benefits that can be mirrored to such investments is lacking. There has been no justification for the proposed projects, tangible benefits cannot be determined. The delays on implementation have adversely impacted negatively on various processes within the port resulting to some of the inefficiencies in the effective delivery of services being experienced. Completion of project within schedule is a major contribution toward the competitive advantage of the organization (Kariungi, 2014). (JICA 2015), report of Mombasa Port Master Plan, explains that Cargo handling capacity of the port has been saturated with the cargo demand already. Consequently, long waiting time for berthing due to berth occupied by another ship and low productivity in cargo handling take place. Stare (2011), concludes that many projects are implemented but they don't bring the benefit intended. 
This study therefore seeks to identify, assess and explain the factors affecting effective delivery the capital works projects in the Port of Mombasa. The result of this study, therefore is meant to improve how capital work projects are handled from Project initiation to closure. This would intern improve on the ports productivity, customer satisfaction through efficient service delivery, hence realizing the vision of being the world-class seaports of choice. It is worth noting that has been conducted to identify causes affecting project performance at the Port of Mombasa (KPA).

\subsection{The Purpose of the Paper}

The general objective of this study was to assess the factors affecting effective projects delivery at the Kenya Ports Authority.

\subsubsection{Specific Objectives}

The study was guided by the following specific objectives;

1. To determine the effect of Project management procurement processes on project performance in Kenya Ports Authority.

2. To find out the effect of project management competency on project performance in the Kenya Ports Authority.

3. To determine how project management structure affects project performance in Kenya Ports Authority.

4. To evaluate how project management organization culture affects project performance in the Kenya Ports Authority

\subsection{Literature Review}

\subsubsection{Project Management Procurement Process}

Procurement function is key to all organization, public or private both locally and international. According to Erikson \&Vennstrom(2009), it is important to know how different procedure (processes) affects different types of projects because different project requires an application of different procedures. The effective public procurement process is crucial for good public services and good government. Charted Institute of Purchasing and Supplies, CIPS (2013), defines procurement as a business management function that ensures identification, sourcing, access and management of the external resources that an organization needs or may need to fulfil its strategic objectives. Procurement exists to explore supply market opportunities and to implement resourcing strategies that deliver the best possible supply outcome to the organization, its stakeholders and customers. Its success can only be ultimately judged or measured when the product has been disposed of or sold on, or when the service contract has been delivered in full.

Despite the importance of procurement economic, social, cultural and political environment of an institution, it is faced with various challenges (Thai, 2001). Some challenges faced include; handling of large procurement outlay, lack of transparency, purchase of unintended or unplanned good or services, lack of fair competition in bids, wastes and corruption, complying with government procurement regulations (Thai, 2001). Owuoth \& Mwangangi (2015), eludes that procurement processes in public institutions are marred with inefficiencies, secrecy and undercutting. Odhiambo \& Kamau (2013) narrates the procurement system has been frequently manipulated through the use of circulars. Despite enactment of the procurement regulations loss of public funds is still evident (Odhiambo \& Kamau, 2013). World Bank (2014) confirms in their report the "good national public procurement practices are major determinants of effectiveness of public expenditures and the processes have effects on development impact." Luyimbazi (2014) eludes that there are four issues that can impact on the procurement process; length of the process, oversight agencies, liberty accorded to complainants, need or due diligence. He further states that effective procurement process is vital for the government and it spans the life cycle from identification of needs, selection of contractor, contract management and disposal, hence procurement determines when to start the project, completion and the quality of outcome. These are determinants of value for money.

According to Asakeya (2014), Ghana procurement function is faced by same problems as the other developing nations and this includes ledger charges, contract variations, cost overruns, payment of uncompleted projects, failure to adhere to PPA guideline amongst others. He further states that 
political interference has impacted very negatively on procurement functions which has led to escalated prices on projects and other related service. Other decisions and also projects have been influenced, hence they don't support the strategic objective of the organization, capricious decisions (Asakeya, 2014). This is supported by Atego \& Theuri (2015) when they eluded that most procurement decisions are of great concern and colossal amount of tax payers' money is lost through dubious procurement which also results in poor quality works. They further opined that cases of padded pricing and late schedule in projects are the order of the day. Mabelebele (2006) also emphasized the loss of tax payer's fortunes due to poorly managed projects in South Africa.

According to Alarcon, Rivas \& Serpell (1999), procurement of capital projects is mainly affected by the delay in schedules and unspecified quality for the projects. Poor management of the procurement process has direct bearing to the inefficiencies which results in missed targets, hence poor performance (Mokoji, Maimura \& Ombui, 2015). In their finding, they further noted the concern of long duration in the procurement process and many weaknesses exhibited by the procurement regulations. According to Asakeya (2014), lack of assessing and planning the procurement process could result in increased costs of project, scope creep, increased project risk and variations, hence the overall project performance will be compromised.

Mutava (2012), eludes that procurement procedures are too long and could not cater for emergencies. Timing is regulatory and stipulated in the Public Procurement and Disposal Act (PPDA) which has been under continuous revision since the year, 2000, the latest revision being 2015. Purpose for embarking on this reforms by the Government was to enhance its efficiency, transparency and obtain the value for money for product or services rendered (RoK, 2009). PPDA document had limitations on the project covered by the Procuring entity and this led to the development of a specific manual which deals with project (RoK, 2009). The manual specify thirteen steps procedure with twenty-two sub-sets before the project is procured or the final award. This take time and it's ineffectiveness on project performance and it hampers the achievement of organization strategic objectives.

According to Yong \& Mustafa, (2012), the procurement method as well as tendering procedure play an important role in ensuring efficient delivery of projects. Basara, (2014) also opined that lack of effective procurement process could equally lead to failure and the procurement issues should be prioritized during project implementation Jeptepkeny (2015), having analyzed some of the variable affecting project performance, she concluded that procurement procedures had a positive effect on the performance of projects From the research model analyzed, procurement process accounted for more than $70 \%$ of efficient delivery of projects. Procurement procedures is one key improvement area that can contribute substantially to project success (Eriksson, 2008a).

\subsubsection{Project Management Competency}

According to Crawford (2005), the definition of competence has attracted debate by many researchers. This research however adopts a definition by Caupin et al (2006), which defines competence as a combined set of an individual's knowledge, abilities, personal characteristics used to perform a specific task or activity. Competency is also defined as "cluster of related knowledge, attitudes, skills and other personal characteristics; that correlates with performance of the job and can be improved through training" (Parry, 1998). Crawford (2005), model classify the competence into input, personal an output, for which he describes input as knowledge and understanding, skills and ability.

The IPMA Competence Baseline divides project manager competencies into three groups: technical, behavioral and contextual (Caupin et al. 2006). The technical competencies refer to competencies related to project management itself, for example, project planning, time management. Behavioral competencies deals with personal abilities and skills of the project manager such as leadership, creativity and commitment. The contextual competencies range involves the competencies related strictly to the context of a specific project, such as development and programming skills, business knowledge, knowledge of legal issues, and others (Capin et al. 2006). The 7-s model dictates the integration of the soft skill in achieving the strategic goal of organization. Similarly, projects aligned to strategic objectives of the organization provides effectiveness and efficient delivery of services. To achieve this, it is of importance that the soft element (Skill, staff, style and the shared value) the 7-s model be integrated in projects. Like any other skill, project management skill and knowledge can be nurtured and developed appropriately. This will enhance project performance 
Various research refers to knowledge, ability, technical skills, amongst other components, as human capital that help the team to focus on the organization goals (Roos, 1998; Stewart, 1997).

Kaklauskas, Amaratunga \& Lill (2010), agrees to the fact that there is a growing awareness of the relationship between the achieving the project success and the construction manager competence. This is supported literatures (Patanakul \& Milosevic 2009; Stevenson \& Starkweather, 2010). Worsely (2009), eludes that still there are problems recruiting project managers with knowledge, skill and experience, though they may possess project management qualifications. Achieving competence is a continuous activity for project managers and as such needs continuous improvement process (Omidvar, Jaryani, Samad, Zatarghandi, Nesab, et al 2011).

Wamae (2014), conducted a study to determine the significance of staff competence on performance and the results indicated that there is a direct correlation between level of education on a particular field and the performance. According to Jerome (2013), project success is, in part, contingent on effectively managing the constraints of time, cost and scope, and in order to achieve this, it is essential for the project manager to possess and display appropriate competence. In his study he indicated that in addition to more emphasized project administration expertise (setting and managing scope, timelines and budget) a project manager must be competent in studying the project task and clarifying scope, communication effectively, developing project objectives, showing reliability and planning project economy. Crawford (1997) asserts that, as a profession and discipline, project management stakeholder's puts more emphasis in the competence of the Project manager and this will help them to perform effectively leading to successful projects and successful organization.

\subsubsection{Project Management Structure}

Gray \& Larson (2011), asserts that project structures provides a framework for initiation and executing projects task in main organizations. According to the Project Management for Development (PM4D) 2007, "PM structure reduces uncertainty and confusion that occurs dung the project initiation and it also establishes the relation between project team members and the external environment." Being one of the critical hard element in Mckinsey 7-s model, structure classifies the organization of a company, its departments, roles and responsibility, and area of expertise aligned to the strategic objective. The structure is essential to project success. PM4D suggest that project structures are established to enable project managers effectively manage their team for effective deliverability of projects.

Project management literature categorizes project structure into three main groups; functional organization, matrix organizations (weak, balanced, strong), and Project based organization (Gray \& Larson, 2011). Other Literatures classify project structures as functional project team, matrix project teams, dedicated project team and autonomous project team. Lechler \& Dvir (2010), suggests that's the functional project managers have no decision authority whereas for the project based organization they have full decision authority while for matrix structure it possesses a dual authority by the virtue of the fact that it's positioned in the midst of the two structures.

Gray \& Larson (2011), description of the functional model; the projects are managed by the functional units who are given the responsibility for completing it projects. Normal management hierarchy is used to coordinate the projects. Project based structures involve the creation of independent project team that has a full authority, hence the existence of the functional manager in the hierarchy is ceremonial; very limited authority or role. PM4D describe the matrix based as "project organization with specific technical competencies whose staff are withdrawn from within the organization. The relative power between the functional manager and the project manager is what leads to the adoption of various matrix structure; weak, balanced and strong matrix. From various project management literature, it is eluded that each structure has its own advantages, and if used correctly and in the right environment, the structure can further the successful completion of projects (Tait 2010). PM structure can either help or hurt project success, mess up your ability to deliver projects. It can either get in the way, or help support the overall success of their projects. Maduenyi, Oke, Fadeyi \& Ajagbe (2015), in their finding, concluded that "performance of an organization largely depends on the structure of the organization." Further they claimed that clear structures enhances individual performance and increase productivity.

According to Hutcheon (2014), megaprojects often experience increased bureaucracy, utilize inadequate systems, and suffer from duplicative, inefficient processes that can confound even the 
savviest technical minds. Whereas smaller projects can be managed with simpler structures, megaprojects, because of their increased organizational complexity require members of the project management team to possess not only technical competency but also well-developed soft skills. These soft skills allow project managers to successfully interface with various parent company factions and negotiate cultural differences between joint venture and consortium partners.

According to Mochal (2003) in his article, he describes various ways in which some PM structures can definitely impair your ability to deliver projects. If your project organization does support as well, issues to do with multitasking and thrashing, inability to share resources or the expertise necessary at a particular point of the project cycle. A number of organizational factors support or inhibit the ability of your project managers to be successful. The organizational structure can also help or hinder your success rate. The structure can determine how well you focus on projects and how easy it is to share resources between organizations.

According to Winfred (2010) thesis, he indicated that studies by different authors reported that the structure adopted for the management of building projects is an important area to consider for the success of projects. Poor project performance will be realized whenever there is a weakness in the project structure regardless of organizational commitment or leadership style. He also asserts that work grouped project management activities that facilitate project success under two main areas, which require the establishment of organizations structure for their effectiveness.

\subsubsection{Project Management Organization Culture}

Kroeber \& Kluckhohn in their very old literature of 1952, critically analyzed the concept and definitions of culture and resulted with 164 different definitions. Culture is difficult to define and despite the effort of some anthropologists trying to define it, there has been no consensus (Apte, 1994). Culture has been defined as "the collective programming of the mind that distinguishes the members of one group or category of people from others" (Hofstede, 2011). It is always a collective phenomenon, but it can be connected to different collectives. Within each collective, there is a variety of individuals. If characteristics of individuals are imagined as varying according to some bell curve; the variation between cultures is the shift of the bell curve when one moves from one society to the other.

Zuo, Zilante \& Coffey (2009) asserted that studies have analyzed the cultural influence at various level; professional culture, industry culture, organizational culture and national culture; and concluded that project culture is a major contributor to project success. Kundu (2001), argues that culture varies with the type of environment and the organizations overall strategy. He further suggested that impact of culture is reflected in management by values, attitudes, people's behaviors. It affects the way people think and behaves (Hodgetts \& Luthans, 1994).Organizational culture has a huge effect on the success rate of projects with organizations.

According to Schein (2010) defines organizational culture as a pattern of shared basic assumptions that was learned by a group as it solved its problem of external adaptation and internal integration that has worked well enough to be considered valid and therefore to be taught to new members as the correct way to perceive, think and feel in relation to those problems. From the literature on culture, it has been realized that there is no clear definition of the project management culture and this has given rise to some authors using these terms synonymously. Some have regarded the project management culture as the culture of project management profession or project team (Du Plessis \& Hoole, 2006). Gray \& Larson (2011), suggests that an ideal culture would balance concern with output and the methodology to achieve those outcomes. He further narrates that the project failure solely depends on the organizational culture in which it is delivered. From the literature of (Du Plessis \& Hoole, 2006, Gray \& Larson, 2011), this research takes into consideration the project management organization culture and it effects to project performance.

According to PMI (2015), understanding organizational culture and its relationship with project management can help businesses determine which projects are worth pursuing. By "embedding the project management mindset in organizational culture" firms may generate long-term benefits in a competitive environment. An organization's culture can be related to the success rate of projects in a number of areas, including processes, management style, time management and training. PMI (2015) further narrates that some industry sources lists the factors embedded in the organization culture that would affect project performance which include : Overall tone of the shared employee experience 
Shared visions, mission statements and expectations Motivation and reward systems, Views on leadership and authority relationships, Work ethic Codes of conduct, Environmental factors, Social norms and Risk tolerance.

Belassi (2013) concludes in his study that the reason behind the high failure rate of New Product Development (NPD) projects stems from the fact that organization tend to maintain the same set up, the same way of doing things, same culture, yet they expect different outcome, they expect to be more successful by changing few project related- related variables. Pinto (2010) suggests that culture affects how department interact and support each other in the achievement of organization objective, the level of commitment, planning processes (how resources are assigned to the projects) and evaluation of team performance and how they perceive outcome.

According to Martin (2012), Organizational culture is not a "one size fits all" concept. No "correct," "proper," or "standard" organizational culture exists; culture is derived from the history of the organization and, in order to be considered healthy, must allow the organization to achieve its mission. Since the external environment plays an important part in the success and failure of an organization, the culture must also allow the organization to relate and adapt to the surrounding community.

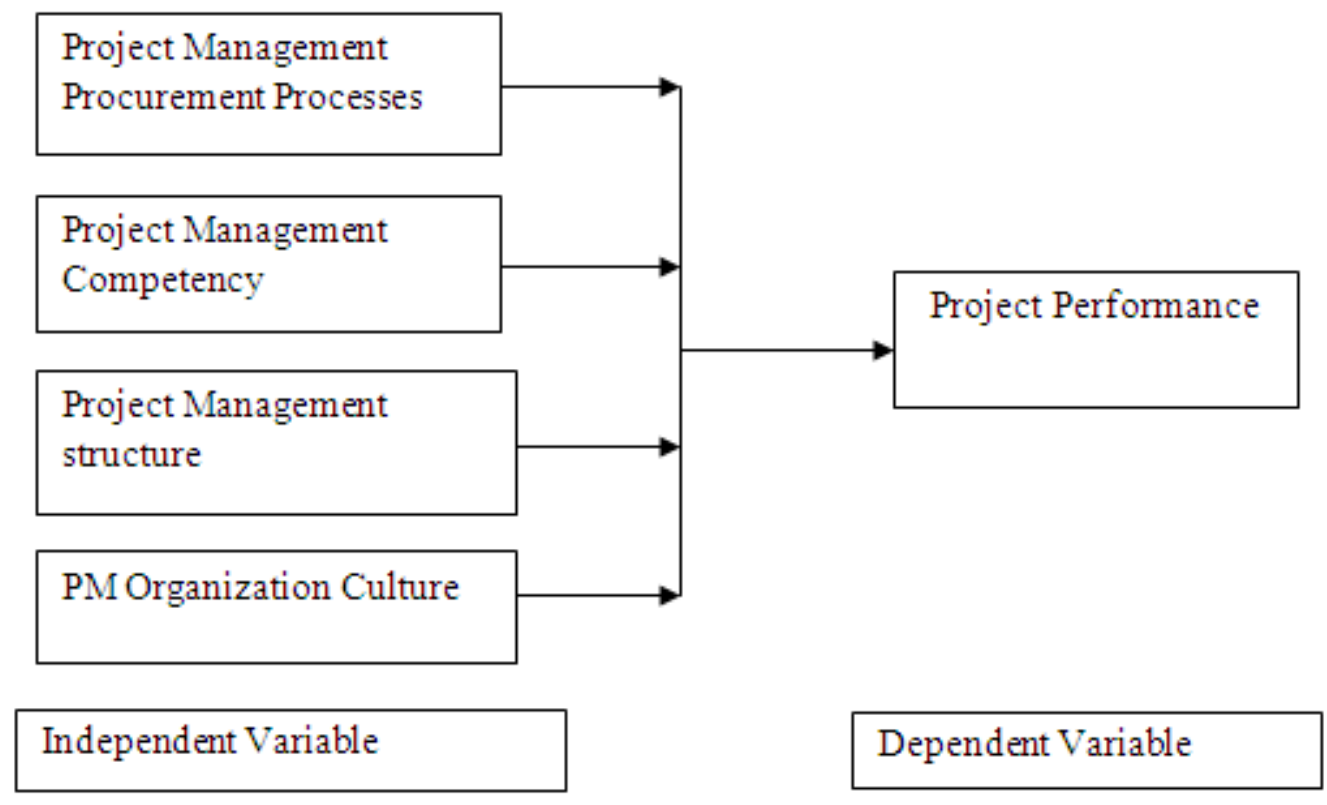

Fig1. Conceptual Framework

\section{Methodology}

The study employed a descriptive research design involving both qualitative and quantitative analysis. The target population of this study was 720 senior personnel officers who are currently or have been previously involved in projects in their departments or specially project assignments for the organization. The response was drawn from officers working in various departments; Engineering, Human Resources, Security, Operations and Procurement. From the stratum, a sample of 72 was drawn translating to $10 \%$ of the total population. The stratified random sampling was applied in order to obtain a representative sample from the population which would enable the data to be analyzed.

Table1.1. Sampling size determination

\begin{tabular}{|l|c|c|c|}
\hline \multicolumn{1}{|c|}{ Stratum } & Target Population & \% Sample Size & Sample Size \\
\hline Engineering & 360 & 10 & 36 \\
\hline Human Resources & 120 & 10 & 12 \\
\hline Security Services & 60 & 10 & 6 \\
\hline Operations & 90 & 10 & 9 \\
\hline Procurement & 90 & 10 & 9 \\
\hline & 720 & 10 & 72 \\
\hline
\end{tabular}

Source: Author Field work (2017) 


\section{Result AND DiscuSSIONS}

\subsection{Response Rate}

The administered questionnaires were collected from the respondent from various departments and 65 out of 72 were filled and collected from the appointed key agents within the departments. This accounted to $90.28 \%$ response rate. It meant that the study suffered a non-response bias of $9.72 \%$. The overwhelming response are was attributed to the fact that majority of the respondent were senior officers in the organization who understand the value of the research and also because of the clear and easy to read designed survey questionnaire. Draugalis, Coons \& Plaza (2008), indicated that most professional articles have failed to define the response rate but Babbie (2007), stated that 50\% response rate is adequate and can be reported, $60 \%$ is good while above $70 \%$ is excellent. Therefore $90.28 \%$ response rate was considered excellent.

\subsection{Reliability Analysis}

Cronbach's alpha $(\alpha)$ coefficient was used to measure the Reliability (internal consistency) of the constructs. The results indicated that the coefficient for the construct were all above the acceptable lower limit of 0.7: PM competence had a coefficient of 0.707 measured against eight constructs, Project Management Structure with a coefficient of 0.747 measured against six constructs and Project Management Organization Culture of 0.753 measure against six constructs. Project performance obtained a coefficient of 0.854 .

Table1.2. Reliability Statistics

\begin{tabular}{|l|c|l|}
\hline \multicolumn{1}{|c|}{ Constructs } & Cronbach's Alpha & \multicolumn{1}{c|}{ Comments } \\
\hline Procurement Process & $0.753>0.7$ & Accepted \\
\hline PM Competency & $0.707>0.7$ & Accepted \\
\hline PM Structure & $0.747>0.7$ & Accepted. \\
\hline PM Organization Culture & $0.753>0.7$ & Accepted \\
\hline Project Performance & $0.854>0.8$ & Better \\
\hline
\end{tabular}

\subsection{Descriptive Statistics}

The respondent distribution by gender, Table 4.3 , show that $76.9 \%$ of the officers were male and $23.1 \%$ were female as indicated in the below table. This was attributed by the fact that the highest number of the respondent were from Engineering and Infrastructure division, a field presumed to be dominated by men. So as to derive a meaningful conclusion from the research data, level of education, experience, and their positions in the organization were critical. Further it was necessary to find out the percentage of the respondents who are either partly handling projects in functional department or wholly for the organization. The quality of the research data were dependent on these parameters.

Table1.3. Gender Analysis

\begin{tabular}{|l|c|c|}
\hline & Frequency & Percent \\
\hline 31-40 years & 21 & 32.3 \\
\hline 41-50 years & 29 & 44.6 \\
\hline Above 50 years & 15 & 23.1 \\
\hline Total & 65 & 100.0 \\
\hline
\end{tabular}

\section{REGRESSION ANALYSIS}

Multiple regression analysis was conducted to predict the value of dependent variable, Effective Project Management based on the predictors or independent variable, Procurement Process, Project Management Competence, Project Management Structure and Project Management Organization culture.

The results was represented as follows: $Y=7.407+0.719 \beta_{1}+0.267 \beta_{2}-0.249 \beta_{3}+0.538 \beta_{4}+\mathcal{E}$.

The coefficient of determination $R^{2}$ and correlation coefficient (r) obtained predicted that Procurement Process, Project Management Competency, Project Management Structure and Project Management Organization culture explains $38.6 \%$ of the variance $\left(\mathrm{R}^{2}=0.386, \mathrm{~F}(4,60)=9.415, \mathrm{p}<\right.$ 0.01 ). This showed that there is moderately strong relation between the dependent variables and the independent variables. 
The model also shows that adjusted $\mathrm{R}^{2}$ was $34.5 \%$, this postulates that the predictors explains $34.5 \%$ of variations in project performance. Further research is recommended to determine other factors affective project delivery at the Port of Mombasa.

Table1.4. Model Summary

\begin{tabular}{|c|c|c|c|c|}
\hline Model & R & R Square & Adjusted R Square & Std. Error \\
\hline 1 & $.621 \mathrm{a}$ & .386 & .345 & 4.486 \\
\hline
\end{tabular}

ANOVA was used to compare the difference of means amongst the various groups, Procurement Process, Project Management Competency, Project Management Structure and Project Management Organization culture. The obtained $F$-ratio of 9.415 described the overall regression model as a good fit for the data. The results showed that predictors statistically significantly predicted the dependent variable, $\mathrm{F}(4,60)=9.415, \mathrm{p}<0.05$.

Table1.5. ANOVA

\begin{tabular}{|l|l|c|c|c|c|c|}
\hline \multicolumn{2}{|c|}{ Model } & Sum of Squares & df & Mean Square & F & Sig. \\
\hline \multirow{3}{*}{1} & Regression & 757.754 & 4 & 189.438 & 9.415 & .000 \\
\cline { 2 - 7 } & Residual & 1207.231 & 60 & 20.121 & & \\
\cline { 2 - 7 } & Total & 1964.985 & 64 & & & \\
\hline
\end{tabular}

\section{Conclusions}

\subsection{Effects of Project Management Procurement Process on Project Performance}

The study concluded that project management procurement process have significant effects on project performance. The project procurement processes of Port of Mombasa is guided by PPDA as any other public entity. The study concluded PPDA play a bigger role in project delays due to bureaucracy in the process. The study concluded that project performance depends on timely execution of the internal processes, procurement planning, seeking of approval, Preparation of project scope, Invitation to Tender, Tender Opening, Tender evaluation and Contract award, managing contracts which exists within the Port of Mombasa. The speedy execution of the processes involved will enhance the project delivery time (Schedule). The study also concludes that customer input is key in preparation of the project specification (Scope) as this will determine the quality of the end product, hence customer satisfaction. The study further concludes that incorrect project specification (scope) will also be a recipe for the delays, cost overruns and unsatisfied end-user. The study also concluded that project are not usually procured with the approved budget contributing to cost over runs. This results from padding estimates during project planning and cost variations due to frequent change of project scopes.

\subsection{Effects of Project Management Competency on Project Performance}

The study concluded that project management competency has a positive insignificant effect on project performance of Kenya Ports Authority (Port of Mombasa), though it acknowledge the if the project management knowledge level is increased, and the project leadership skill are enhanced then project performance will be considerably improved. This will ultimately prevent delay, cost overrun, customer satisfaction level increase and return on investment for the port. The study also concludes that for the Port of Mombasa to get value for money on projects, professionalism through certification in Project Management was found to be important factor in improving project performance. The study further concluded that not all team members involved in projects are result oriented, hence this extensively affects project performance. This factor impacts on delays and to a large extent on cost of the project.

\subsection{Effects of Project Management Structure on Project Performance}

Arising from the findings stepwise regression, the study concluded that there was a weak negative insignificant effect of project management structure on project performance. The study concluded that project originate from the need by the functional departments, hence not influenced by seniors manager or politicians. Additionally, it concluded even though projects originate from functional unit which could affect there speedy delivery, teamwork is essential for their good performance. The study further concluded that the number of projects executed at a go are numerous, yet the capacity to effectively handle them is inadequate which affects how fast they are being handled. The study also concluded that specialized workforce handling project is key to the organizational performance. This 
meant that a project team established within the structure of the organization would add value and ultimately impact on productivity, hence business performance.

\subsection{Effects of Project Management Organization Culture on Project Performance}

The findings on effects of Project management organization culture directed to a conclusion that culture has a strong positive and significantly affects project performance. The study also revealed that culturally project management is not considered to be an essential component at the Port of Mombasa, though there is a general believe that it contribute to poor project performance. The study further concluded that little or no effort is put in place to continuously monitor and evaluate projects without due consideration of the fact that lack of this culture will always lead to poor quality project not meeting customer/end-users needs. There was no central office established to oversee projects for the organization since there was a varied opinion on where the projects are monitored. This has an impact on business performance for the organization. The study further concluded that personnel do not share the same value and believes when it comes to project goals. Without actualizing the project goals, this will mean a higher probability of not delivering the project need to the end user. The study also concluded that it is unclear the role of top management in supporting the project from the functional department and this could be due to the nature in which the project are initiated and the value they intend to create to the strategic objective of the organization.

\section{RECOMMENDATIONS}

\subsection{Project Management Procurement Process on Project Performance}

As a public institution PPDA plays a critical role in determining the length of time for procuring projects. The study therefore recommend that the PPDA be reviewed to accommodate views of the end users. Port of Mombasa also has internal processes of governing the projects which has an input in the time span of projects. Since time is a key variable in projects it is recommended that the management should review all the projects internal processes with a view of eliminating duplication or redundant processes that would affect the speedy delivery of project within schedule. The study also recommends that customers/end users should be involved at every stage in the project cycle so as to understand and own the project after completion. This would ensure that quality is not compromised and prevent abandoned project after completion. Project are meant to provide solutions to problems, hence it is critical that the scope or specification for the projects are mapped correctly to articulate the need for the end user. The study further recommends market research for similar projects proposed by the end users so as to establish the estimated costs, time period and quality. This will ensure realistic estimates are provided before project approval and cost variations circumvented.

\subsection{Project Management Competency on Project Performance}

Projects needs to be strategically aligned to the strategic objective, hence their performance would directly impact on the business of the organization and for this reason it is critical that the project manager should possess vast knowledge and skills that would translate project goals to the desired outcome. Based on the research findings and conclusions, the study recommends that the management should consider improving the competencies of all project managers. The leadership style: emotional intelligence, management focus and intellect plays a key role in project criteria and project success (Muller \& Turner, 2007).

The study further recommends certification of all the project managers and their team member. Why certifications of the project managers yet results are always achieved. Project management certification similar to any profession is associated to discipline in the profession. Meridith Levinson in her article dated 2010, eluded that being certified is an indicative of attaining a certain level of knowledge and expertise which will make one work proficiently in project environment. The study conducted by Muller \& Turner (2007) supported this fact when they concluded that certified project managers scored high rating in terms of project success than non-certified project managers. Therefore the recommendation for all the project managers and their teams will ensure higher project performance, hence attaining of strategic goals for the Port of Mombasa.

The study also recommends that the management should consider introducing performance measures for all the project manager and their team members based. This will force all team members to be result oriented which will ultimately improve project performance for the Port of Mombasa 


\subsection{Project Management Structure on Project Performance}

Projects at the Port of Mombasa are need based according to the conclusion of this study and they usually originate from functional department according to the organizational structure. This is because there isn't an existing project management team. This functional structure that exist in department is not favorable for project performance because focus and responsibility are not very clear, and the success of a project is linked to performance of another department. The study therefore recommends establishment of project structures within the existing organizational structure which will co-ordinate, monitored and evaluate all the projects and provide feedback or report to senior manager and the board on regular basis. This will help the organization improve on the project performance, hence impact on business.

To get value of money for the projects being handled at departmental levels the management need to critical look into all the proposed projects, their objective and how they are aligned to the strategic objective of the organization. Proper justification for all proposed projects must be provided for approval by the management. Too many projects within a financial year are not essay to manage with especially with inadequate number of staff in project sections. This only leads to lack of structure will deliver this mandate. Project effectiveness is compromised.

\subsection{Project Management Organization Culture Project Performance}

Based on the findings and conclusions, the study recommends that a specialized team be established to continuously monitor and evaluate all the projects on-going in the organization. This will ensure project reports are always provided to the management to appreciate the progress made before completion. This study further recommends the management should instil the culture where project goal becomes a shared vision amongst the employees. The role of top management should the very clear on project undertaken in the Port of Mombasa. It should be very certain to every employee how management supports projects. Therefore, this study recommends that the top management needs to identify themselves and own all the projects carried out in the functional department. Failure or success of this projects affects organizational performance, hence to ensure successful project performance the top management should be interested in the business impact that this project would deliver and not just the output considering the heavy capital investment being made.

\section{Areas of Further Research}

This study focused on key area within the Port of Mombasa which is considered a determinant for the business success. The limitation of this study though is that only one Port exist in Kenya, therefore these results cannot be replicated for any other study in different environment except for the port though the study can be reference. Therefore the researcher recommends for a similar study in any of the Ports in Africa, and also the world leading Ports: Shanghai, Singapore and Shenzhen in china at least to compare the results. The study also recommends for a research within the Port of Mombasa that will extensively focus on Project Management Competency as a determinant for the organization project performance.

\section{REFERENCES}

[1] Abe, K \& J Wilson (2009), 'Weathering the Storm: Investing in Port Infrastructure to Lower Trade Costs in East Asia', World Bank Policy Research Working Paper 4911.

[2] Aniagyei, W. (2011). The Effects of Organizational Structure on project Performance: The case of AGA Ltd: A Thesis Submitted to the Institute of Distant Learning, Kwame Nkrumah University of Science and Technology.

[3] Asakeya G. K. (2014). Impact of Procurement Planning within Ghana Health Services; A Study of Ridge Hospital - ACCRA. A Project Submitted to Kwame Nkrumah University of Science and Technology, Kumasi.

[4] Atego, C. O, \& Theuri F.S. (2015). Effects of Public Procurement Processes on Organization Performance. An International Journal of Scientific and Research Publications, Volume 5, Issue 9.

[5] Alarcon, L.F, Rivas, R \& Serpell, A. (1999). Evaluation of The Procurement Process in Construction Industry. Proceedings IGLC-7, University of California, Berkeley, CA, USA.

[6] Apte, M (1994). Language in sociocultural context. In R. E. Asher (Ed.), The Encyclopedia of Language and Linguistics, 4, 2000-2010. Oxford: Pergamon Press 
[7] Babbie, E. (2007) Conducting Qualitative Field Research. In the Practice of Social Science Research ( $11^{\text {th }}$ Edition) USA.:Thomson Wadsworth.

[8] B Bauer, B. J., Richardson, T. M., \& Marion, J. W. (2014). Project Manager 'Management Competency' vs. 'Technical Competency'. Which Is More Important to Overall Project Management Success. International Journal of Engineering Research and Applications, 4(4 (Version 1). Retrieved from http://commons.erau.edu/publication/60.

[9] Belassi, W (2013), The Impact of organizational Culture on the success of the New Product Development Project: A theoretical Framework of the Missing Link. Faculty of Business, Athbasca University.

[10]Basara, H. W. (2014). Procurement Practices affecting Effective Project Implementation in Kenya: A Case Study of Kenya Civil Aviation Authority. European Journal of Business Management, 6(6), 49-67.

[11]Caupin, G., Knoepfel, H., Koch, G., Pannenbäcker, K., Pérez-Polo, F. \& Seabury, C.( 2006), ICB - IPMA Competency Baseline - version 3, International Project Management Association, Netherlands.

[12]CIPS (2013). The Definitions of 'Procurement' and 'Supply Chain Management'- CIPS Australasia.

[13] Crawford, L. H. (1997). A global approach to project management competency. Paper presented at the AIPM National Conference, Gold Coast, Brisbane.

[14]Du Plessis, Y \& Hoole, C. (2006). An Operational Project Management Culture Framework (Part1); SA Journal of Human Resource Management, 4(1), 36-43.

[15]Draugalis, JR, Coons SJ \& Plaza CM (2008). Best practices for survey research reports: A synopsis for authors and reviewers. Am J Pharm Educ.; 72: Article 11.

[16]Erikson, P. E \& Vennstrom, A. (2009). Effects of Procurement on Project Performance: A Survey of Swedish Construction clients.

[17]Eriksson, P. E. (2008a) 'Procurement Effects on Competition in Client-Contractor Relationships'. Journal of Construction Engineering and Management, 134 (2), 103- 111.

[18] Godwin, I (2012)," Influence of project plans on the outcome of construction projects procured by Design-Build (DB) in Nigeria, Department of Building, University of Lagos, Akoka, Yaba.

[19] Gray, C. F \& Larson, E. W. (2011). Project Management - The Managerial Process. Irwin McGraw-Hill, USA.

[20] Hodgetts, R. \& Luthans, F. (1994). International Management, London: McGraw, Hill.

[21] Hutcheon, D. (2014), The effect of Organizational Structure on the Successful Delivery of Megascale Construction Projects.

[22] Jeptepkeny, P (2015). "Effects of procurement procedure on project performance: A Case study of light construction projects at the Kenya Ports Authority" European Journal of Logistics Purchasing and Supply Chain Management Vol.3, No.1, pp.1-11, March 2015.

[23]JICA. (2015). Final Report Mombasa Port Master Plan including Dongo Kundu. The Overseas Coastal Area Development Institute of Japan Oriental Consultants

[24] Kariungi, S. M. (2014). Determinant of Timely Completion of Projects in Kenya: A Case of Kenya Power and Lighting Company, Thika ABC Journal of Advanced Research, 3, 9 - 19.

[25] Kaklauskas, A., Amaratunga, D, \& Lill, I. (2010), The life cycle process model for efficient constructions Managers: conceptual modeling at the level of personality and Micro, Meso and Macro-levels: In proceeding of the construction, Building and Real Estate Research

Conference of the Royal Institution of Chartered Surveyors. Dauphine Universities; Paris $1-25$

[26]Lechler, T., Dvir, D., (2010). An Alternative Taxonomy of Project Management Structures: Linking of Project Management Structures and Project Success. IEEE Transactions on Engineering and Management, 57(2), 198-210

[27]Luyimbazi, D. (2014) Effect of Procurement Procedures and Project Implementation on Resource Absorption, Uganda National Road Authority, 2014.

[28] Martin, J. (2012). That's How We Do Things Around Here: Organizational Culture (And Change) in Libraries. 
[29] Mabelebele, J. M. (2006). Prospects and Challenges of Implementing Projects in Public Services, South Africa: Proceeding of the PMSA International Conference, Johannesburg, S.A.

[30] Mochal, T. (2003), Organizational culture and structure influence project management more than you realize, Tech Republic Project Management.

[31] Mokoji, W. N, Mairura, C \& Ombui, K. (2015). Effects of Procurement Practices on the performance of Commercial State Owned Enterprises In Nairobi County. International Journal of Scientific and Research Publication, Vol 5, Issue 6. ISSN 2250-3153

[32] Mutava, C. (2012), Impact Of Public Procurement Procedures On Delivery Of Maintenance Works A Research Project submitted to the School of the Built Environment, University of Nairobi.

[33] Mugenda, O. M \& Mugenda, A. G. (2003). Research Methods, Quantitative and Qualitative Approaches: Act Press.

[34] Njagi, L. K \& Malel, J. (2012). Time Management and Job Performance in Selected Parastatals In Kenya. Australian Journal of Business and Management Research. Vol 5 No.5, 19-29.

[35] Owuoth, G. G \& Mwangangi, P. (2015). Effects of Public of Public Procurement Regulations on Procurement performance in Public sectors in Kenya: A Case Study of Rural Electrification Authority.

[36] Odhiambo, W \& Kamau, P. (2013). Public Procurement: Lessons From Kenya, Tanzania and Uganda. OECD Working Paper No. 208.

[37]Parry, S. (1998). Project Management Competency Development Framework, Project Management Institute.

[38] 38. Patanakul, P. \& Milosevic, D. (2009). The effectiveness in managing a group of multiple projects: Factors of influence and measurement criteria, International Journal of Project Management, vol. 27, 3, 216-233.

[39] Pinto, J, K. (2010). Project Management; Achieving Competitive advantage. (2 ${ }^{\text {nd }}$ Edition) New Jersey: Prentice Hall.

[40] PMI. (2015). Capturing the value of Project Management Through the Organizational Agility.

[41] Republic of Kenya, (2007). Kenya Vision 2030.

[42] Republic of Kenya (2009). Manual for Procurement and Management Public Procurement Oversight Authority (PPOA).

[43] Republic of Kenya (2014). Kenya National Bureau of Statistic - An Economic Survey.

[44] Republic of Kenya (2014). Kenya National Audit Office Report on The Financial Statements of East African Trade And Transport Facilitation Project- Ida Credit No. 4148-Ke.

[45]Roos, J. (1998). Exploring the Concept of Intellectual Capital(IC). Long Range Planning, 31910, 150-153. http://dx.doi.org/10.1016/S0024-6301(97)87431-6

[46] Stare, A. (2011). The Impact of the Organizational Structure and Organizational Culture on Project Performance in the Slovenian Enterprises. Management Vol. 16, 2, 1-22.

[47] Stevenson, D. H., \& Starkweather, J. A. (2010). PM critical competency index: IT execs prefer soft skills. International Journal of Project Management, 28(7), 663-671.

[48] Tait, R. (2010). Types of Organizational Structures. Retrieved http://www.articlearn.com/project-management-organizational-structures-paper.

[49] Trade Mark East Africa, TMEA. (2014). Baseline Study For Mombasa Port Corridor Charter Thai, K. V. (2001). Public Procurement Re-examined. Journal of Public Procurement, 1 (1): 9-50.

[50] Wamae, J. W. (2014). Role of Procurement Function in Enhancing Performance in Devolved Government: A Case of Machakos County. International Journal of Social Science and Entrepreneur. 1(11), 168-190.

[51]World Bank, (2010). Kenya Economic Update: Running on One Engine, Kenya Uneven Economic Performance with Special Focus on Port of Mombasa, edition 2.

[52] Yong, Y. C \& Mustafa, N. E. (2012). Engineering, Construction and Architectural Management Vol. 19 Issue: 5: Analysis of factors critical to construction project success in Malaysia.

[53]Zuo, J, Zilante, G \& Coffey, V. (2009). Project Culture in the Chinese Construction Industry: Perceptions of Contractors: The Australian Journal of Construction Economics and Building, $9(2)$. 


\section{AUTHORS' BIOGRAPHY}

Jafeth Juma Akira, is a Kenyan Citizen, aged 45 years and holds a Bachelor of Science in Mechanical Engineering. He is currently pursuing MSC degree in Project Management at Jomo Kenyatta University of Agriculture and Technology, Kenya. Apart from being a student, Jafeth works as a Senior Engineer in--charge of Maintenance of Rubber Tyre Gantry cranes at the Port of Mombasa (Kenya Ports Authority). The author is also a specialist in Vibration Analysis and trained in the USA. Jafeth is also a Graduate Member of Engineers Registration Board and Institution of Mechanical Engineers of Kenya.

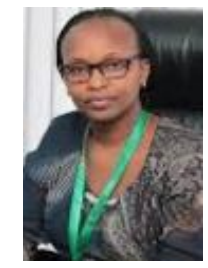

Dr. Fridah S. Theuri, Ph.D is a Director and a Lecturer at the Jomo Kenya University of Agriculture and Technology_ Kenya who supervised my research project together with the publication paper. 